\title{
Lyme Disease: antibodies against Borrelia burgdorferi in farm workers in Argentina
}

\author{
Nestor Oscar Stanchi*, Laura Josefina Balague**
}

STANCHI, N. O. \& BALAGUE, L. J. Lyme disease: antibodies against Borrelia burgdorferi in farm workers in Argentina. Rev. Saúde Pública, 27: 305-7, 1993. Lyme Disease is a tick-borne (specially by Ixodes ticks) immune-mediated inflammatory disorder caused by a newly recognize spirochete, Borrelia burgdorferi. Indirect fluorescent antibody (IF) staining methods and enzyme-linked immunosorbent assay are frequently relied upon to confirm Lyme borreliosis infections. Although serologic testing for antibodies has limitations, it is still the only practical means of confirming $B$. burgdorferi infections. Because we have no previous report of Lyme disease in human inhabitants in Argentina, a study was designed as a seroepidemiologic investigation of the immune response to $B$. burgdorferi in farm workers of Argentina with arthritis symptoms. Three out of 28 sera were positive (\# 1, 5 and 9). Serum \# 1 was positive for Immunoglobulin $G$ at dilution 1:320, serum \# 5 and \# 9 both to dilution 1:160; while for Immunoglobulin $M$ all (\#1,5 and 9) were positive at low dilution $(1: 40)$ using IF. The results showed that antibodies against $B$. burgdorferi are present in an Argentinian population. Thus caution should be exercised in the clinical interpretation of arthritis until the presence of $B$. burgdorferi be confirmed by culture in specific media.

Keywords: Lyme disease, diagnostic. Borrelia burgdorferi, imunology. Rural workers. Antibodies, bacterial.

\section{Introduction}

Lyme Disease is a tick-borne (specially by Ixodes ticks) immune-mediated inflammatory disorder caused by a newly recognize spirochete, Borrelia burgdorferi ${ }^{7}$. Indirect fluorescent antibody (IF) staining methods and enzyme-linked immunosorbent assay are frequently relied upon to confirm Lyme borreliosis infections ${ }^{5}$. These antibody tests are particularly useful when the clinical presentation is unclear ${ }^{5}$. Erythema migrans, an expanding skin lesion that often develops at the site of a tick bite, is the best clinical marker for Lyme disease $^{4,11}$. Although serological testing for antibodies has limitations, it is still the only practical means of confirming $B$. burgdorferi infections ${ }^{4,11}$.

Clinically Lyme disease can be divided into three stages: i) Erythema chronicum migrans rash, ii) neurological complications and migratory musculoskeletal pain (not always expressed) and iii) typically involves the onset of arthritis. Joint problems characteristic of rheumatoid arthritis occur in about $60 \%$ of Lyme disease patients ${ }^{2}$.

\footnotetext{
* Faculty of Veterinary Science. National University of La Plata Argentina

* Bacteriology Laboratory. Instituto del Diagnóstico. La Plata Argentina
}

Reprints: N.O. Stanchi - CC 296 (1900) La Plata, Bs.As.Argentina
We have no previous report of Lyme Disease in human inhabitants in Argentina, on the other hand Mazzonelli et $\mathrm{al}^{8}$ found $23 \%$ of dogs positive in the city of Rosario (Argentina). This study was designed as a seroepidemiologic investigation of the immune response to $B$. burgdorferi in farm workers of Argentina with arthritis symptoms.

\section{Material and Method}

Sera were collected in the laboratory from 28 farm workers, referred to by physicians as having special clinical diagnostic of arthritis. On the other hand 25 normal farm workers (with no present or previous reported arthritis) from the same geographical area, were bled for testing for Lyme, as a control group. To detect antibodies an IF technique was performed essentially as described by Lane $^{3}$ using slides prepared in the Leptospira Reference Center, Hereford (Great Britain).

Briefly, serial twofold dilutions of the sera were prepared from an initial dilution of 1:160 in Phosphate buffered saline (PBS); the slides were incubated in a humidified chamber at $37^{\circ} \mathrm{C}$. for 30 min. The slides were then washed three times with or soaked in PBS and air dried. Fluorescein isothiocyanate-labeled goat anti-human immunoglobulin polyvalent conjugate (Kallestad, USA) was applied to each well and incubated as describe 
above, and the slides were washed twice with PBS and rinsed in distilled water.

The slides were mounted with cover slips, and the wells were examined by fluorescence microscopy. The same procedure but preparing starting dilution of 1:40 were performed with anti-human immunoglobulin M conjugates (Kallestad, USA).

All positive sera were tested by the use of the Microscopic Agglutination Test (MAT) for Leptospirosis using all 10 strains representative of 10 serogroups including serovar patoc, Patoc 1 of $L$. biflexa. In the same way, positive sera were also tested for syphilis with Venereal Disease Research Laboratory antigen (VDRL). Complementary studies were undertaken with Rheumatoid Factor $(\mathrm{RF})$, Protein $\mathrm{C}$ reactive (PCR) and anti streptolysin O (ASTO) (Wiener Lab. Argentina).

\section{Results}

Three out of 28 sera were positive (\# 1,5 and 9). Serum \# 1 was positive for Immunoglobulin $G$ at dilution 1:320, serum \# 5 and \# 9 both at dilution 1:160; while for Immunoglobulin $\mathrm{M}$ all ( $\# 1,5$ and 9) were positive at low dilution (1:40) using IF.

Serum \# 3 both IgG and IgM showed only weak fluorescence and they were considered negative. All three sera tested for Leptospiras (MAT) were negative, and were also non-reactive when antibodies to Treponema pallidum (VDRL) were investigated. Serum \# 5 was positive to Rheumatoid factor (RF), but was negative to ASTO and PCR. Sera \# 1 and 9 were negative to RF, ASTO and PCR.

All control groups showed non reactive sera to B. burgdorferi.

\section{Discussion}

B. burgdorferi has been demonstrate in ticks, mosquitoes and deer flies, but only ticks of the Ixodes complex seem to be important in the transmission of the spirochete to humans ${ }^{11}$. In Argentina different ticks of the family Ixodidae have been incriminated in transmission of zoonosis in human beings, i.e. Amblyomma cajannense, A. maculatum, A. striatum; Boophilus microplus; Rhipicephalus sanguineus; and in the family Argasidae Ornithodorus rostratus and $O$. talaje are the most important ${ }^{1,9}$.

Testing for Lyme disease may produce falsepositive reactions. Cross reactivity with antibodies to Treponema pallidum is well document$e d^{6,10}$. However, in our investigation VDRL was non reactive in all the three positive sera for
Lyme. Less is known about the nonspecific antibodies produced to oral treponemas, but are usually of low concentration. The possible crossreaction with Leptospiras serovars was excluded by the use of MAT with all the representative strains of 10 serogroups (those previously founded in Argentina). Antibodies produced by different species of Borrelia are highly cross-reactive with $B$. burgdorferi; but other Borrelia species are found cnly in inhabitants of Northern Argentina. The Rheumatoid factor IgM antibody in serum also cross-reacts in tests for Lyme disease, but this seems to occur infrequently ${ }^{4}$, serum \# 5 was positive (low titer) to RF. On the other hand sera \# 1 and 9 were negative to RF.

This investigation shows that antibodies to $B$. burgdorferi are present in an argentinian population. Thus caution should be exercised in the clinical interpretation of arthritis until the presence of $B$. burgdorferi be confirmed by culture in specific media.

STANCHI, N. O. \& BALAGUE, L. J. [Doença de Lyme: anticorpos anti Borrelia burgdorferi nos trabalhadores rurais da Argentina]. Rev. Saúde Pública, 27: 305-7, 1993. A doença de Lyme, é, uma desordem inflamatória, intermediada pelo sistema imunogênico, transmitida por carrapatos (especialmente do Gênero Ixodes) e causada por uma espiroqueta recentemente descoberta, a Borrelia burgdorferi. A técnica de Imunofluorescência Indireta (IF) é com frequêência usada para confirmar o diagnóstico da infecção por este microrganismo. Embora os métodos práticos tenham limitações, é no entanto o único método prático para seu diagnóstico. Devido a não existência de registros prévios dessa doença na Argentina, foi realizada pesquisa seroepidemiológica para determinar a presença de imunoglobulinas nos trabalhadores rurais da Argentina, com sintomas de artrite. Sobre um total de 28 soros analisados, 3 resultaram positivos (o soro número $1 \mathrm{com}$ um título de 1:320 para $\operatorname{IgG}$, embora os soros números 5 e 9 ambos foram reativos a diluição 1:160). Esses mesmos soros foram analisados para a IgM sendo todos eles levemente reativos (1:40), usando IF. Os resultados mostram que anticorpos anti Borrelia burgdorferi se encontram presentes na população da Argentina. Deve-se ter, portanto, precaução na interpretação clínica das artrites até que a presença de Borrelia burgdorferi seja confirmada pelo cultivo nos meios específicos.

Descritores: Doença de Lyme, diagnóstico. Borrelia Burgdorferi, imunologia. Trabalhadores rurais. Anticorpos anti-bactérias.

\section{Acnowledgments}

We are greateful to Drs. S. Waitkings and J. Hookey for provision of the $B$. burgdorferi slides. 


\section{References}

1. BOERO, J.J. Las garrapatas de la República Argentina (Acarina - Ixodoidea). Buenos Aires, Universidad de Buenos Aires, Departamento Editorial, 1957.

2. BUKOWSKI, J.A. Lyme disease: a tick-borne threat topeoples and pets. Pet.Practice Vet.Med ., April:346-58, 1988.

3. LANE, R.S.; LENNETTE, E.T.; MADIGAN, J.E. Interlaboratory and intralaboratory comparisons of indirect immunofluorescence assays for serodiagnosis of Lyme disease. J. Clin. Microbiol., 28: 1774-9, 1990.

4. MAGNARELLI, L.A. Serologic testing for Lyme disease. Postgrad. Med,. 87: 149-50, 153, 1990.

5. MAGNARELLI, L.A.; MILLER, J.N.; ANDERSON, J.F.; RIVIERE, G.R. Cross-reactivity of nonspecific treponemal antibodies in serologic test for Lyme disease. $J$. Clin. Microbiol., 28: 1276-9, 1987.

6. MAGNARELLI, L.A.; ANDERSON, J.F.; JONHSON, R.C. Cross-reactivity in serological test for Lyme disease and other spirochetal infections. J. Infect. Dis., 156: 183-8, 1987.
7. MALAWISTA, S.E. Phathogenesis of Lyme disease. Rheumatol. Int., 9: 233-5, 1989.

8. MAZZONELL, J.; HUTTER, E.; BRHHUEGA, B.; LABALLEN, H. Borreliosis de Lyme: encuesta serológica en perros. In: Proceding of the Anual Associación Argentina Veterinária Laboratorio Diagnostico, 4", Tandil, Argentina, 1988.

9 . NUNEZ, J.L.; MUNOZ COBENAS, M.E.; MOLTEDO, H. Boophilus microplus: la garrapata común del ganado vacuno. Buenos Aires, Ed. Hemisferio Sur, 1987.

10. RUSSEL, H.; SAMPSON, J.S.; SCHMID, G.P. Enzymelinked immunosorbent assay and indirect immunofluorescence assay for Lyme disease. I. Infect. Dis., 149: 465-70, 1984.

11. STEERE, A.C. Lyme disease. N. Eng. J. Med., 31: 586-96, 1989.

Recebido para publicação em 14.9.1992
Reapresentado em 1.4.1993 Aprovado para publicaçấo em 15.6.1993 